\title{
Productive traits, selenium status and blood metabolic status in fattening lambs affected by selenium biofortified corn
}

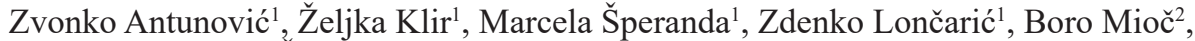 \\ Nina Čebulj Kadunc ${ }^{3}$, Danijela Samac ${ }^{1}$, Josip Novoselec ${ }^{1}$
}

${ }^{1}$ J. J. Strossmayer University of Osijek, Faculty of Agrobiotechnical Sciences Osijek, Osijek, Croatia ${ }^{2}$ University of Zagreb, Faculty of Agriculture, Department of Animal Science and Technology, Zagreb, Croatia ${ }^{3}$ University of Ljubljana, Faculty of Veterinary Medicine, Ljubljana, Slovenia

\author{
Received November 7, 2019 \\ Accepted April 30, 2020
}

\begin{abstract}
The widespread selenium (Se) deficiency in soil and in feedstuffs from such soil, needs to be prevented by various methods. Recently, biofortification of Se has been carried out by soil fertilization and foliar application of crops. The aim of this study was evaluate the productive traits, Se status and blood metabolic profile in fattening lambs affected by Se biofortified corn. The research was conducted with 20 Merinolandschaf lambs of the average age of 70 days, during 30 days of fattening. The feed mixture of the control group contained corn $(0.014 \mathrm{mg} \mathrm{Se} / \mathrm{kg}$ dry matter, DM); in the experimental group (Se-BC), corn was biofortified $(0.278 \mathrm{mg} \mathrm{Se} / \mathrm{kg}$ $\mathrm{DM})$. The feed mixture, hay and water were offered to lambs ad libitum. Blood was collected from the jugular vein on days 0 and 30 of experiment. Haematological indices were determined in whole blood, whereas concentrations of biochemical indices, enzyme activities, and concentrations of metabolic hormones were determined in serum. After the slaughter, samples of musculus semimembranosus, liver, kidney, lungs, spleen, peritoneum and heart tissues were taken. No significant differences were obtained in productive traits when feeding lambs with SeBC. Higher concentrations of Se in lungs and liver (control: 0.26 and $0.75 \mathrm{mg} / \mathrm{kg}$, respectively; Se-BC: 0.33 and $0.92 \mathrm{mg} / \mathrm{kg}$, respectively) was determined in Se-BC compared to control. Higher activity of glutathione peroxidase enzyme in serum, higher erythrocyte count, higher content of haemoglobin and haematocrit in whole blood of Se-BC lambs were determined. The results of the study indicate the posibility of using Se-BC in lambs' diets.
\end{abstract}

Biofortification, lambs, blood parameters, production, selenium

Selenium (Se) is an essential trace element for animals and humans, and has multiple biological activities. Thus, low dietary intake of Se can cause health disorders in humans and animals (Gianidis et al. 2016). In livestock, Se deficiency is also responsible for the white muscle disease, with clinical signs that include lesions in skeletal and/or hearth muscle (Malagoli et al. 2015). It is well known that Se is a major component of a number of functional selenoproteins such as glutathione peroxidase (GPx), iodothyronine deiodinase and thioredoxin reductase, which protect the cell membrane from lipid peroxidation.

The lack of Se in food can be eliminated by its dietary supplementation, by enriching food with Se (fortification) and increasing Se concentrations in feedstuffs (biofortification) (Stein 2010; Novoselec et al. 2018). Agronomic biofortification of food crops, especially staples such as cereals, which are consumed widely, may be an effective component of a food system strategy to reduce Se malnutrition (Ly ons 2018). In Se deficient areas, several means of selective supplementation are available, e.g. organic Se-yeast can be added to the feed, or inorganic sodium selenite can be added to mineral mixes for free choice consumption (Hall et al. 2017). Biofortification refers to the application of mineral fertilizers to desired crops, combined with grains with increased ability to adopt microelements as an approach not only to increase the concentration of microelements in edible crops but also to

Address for correspondence:

Željka Klir

Department for Animal Production and Biotechnology

Faculty of Agrobiotechnical Sciences Osijek

Phone: +38531554906

J. J. Strossmayer University of Osijek, Osijek, Croatia 
improve the yield on soils where microelements or Se are exhausted or unavailable (Borg et al. 2009). Plants assimilate Se as selenate, selenite or organic Se compounds such as selenocysteine (SeCys) and selenomethionine (SeMet) but cannot assimilate elemental Se or metal selenides (White et al. 2004). The selenates are transported through the membrane of the roots by high-affinity sulphate transporter and Se by phosphate transporters ( $\mathrm{Li}$ et al. 2008). Selenite is soon converted to organic Se compounds, while Se is transferred to xylenes and assimilated into organic Se compounds and distributed within the plant. In recent years, research has been carried out on biofortification, or enrichment of forage with Se (pasture and hay) and their effect on animal productivity and animal health. Besides, Hall et al. (2009) investigated the Se status in sheep grazing the pastures fertilised with Se in areas with normally low forage Se concentrations which resulted in significantly higher concentrations of Se in whole blood of sheep. Hall et al. (2013) reported a significant linear increase in the concentration of blood Se and body weight of weaned calves fed with bio-fortified alfalfa hay during 7 weeks. Feeding cows in lactation with Se-enriched silage showed greater bioavailability of Se in milk and blood as well as similar production traits compared to cows fed with silage containing addition of Se-yeast as well as to cows fed with addition of inorganic Se-silage (Séboussi et al. 2016). Mehdi et al. (2015) found a significant increase in the concentration of Se in the muscles, lungs, kidneys, liver and plasma of young beef bulls fed cereals enriched with Se (barley and spelt). Monitoring of the metabolic profile by determining the concentration of biochemical and haematological indices in the blood of small ruminants gives us a clearer picture of their nutritional and health status even before the changes are visible in the animal (Antunović et al. 2017). Considering that Southeastern Europe is a deficient in Se concentrations of soil (Pešut et al. 2004; Antunović et al. 2010a; Valčić et al. 2013; Ademi et al. 2015), biofortification could be a good solution to overcome Se deficiency in the animal-human chain. Thus, the aim of this study was to research whether the addition of Se biofortified corn in diets influences the production traits, Se status and metabolic profile of fattening lambs.

\section{Materials and Methods}

Bioethics Committee for Research on Animals of the Faculty of Agrobiotechnical Sciences Osijek established that the research was carried out under the legal provisions of Animal Protection Act (NN 133/06, NN 37/13, and NN 125/13).

\section{Animals and feeding}

The research was conducted on 20 Merinolandschaf lambs after weaning, of the average age of 70 days, during 30 days of fattening. The lambs which were in good health and evenly represented in terms of sex $(50 \%$ : $50 \%$ ऊ) were divided in two groups. The feed mixture of the control group contained $23 \%$ corn $(0.014 \mathrm{mg} \mathrm{Se} / \mathrm{kg}$ dry matter, DM), while $23 \%$ biofortified corn $(0.278 \mathrm{mg} \mathrm{Se} / \mathrm{kg} \mathrm{DM})$ was used in the experimental group (Se-BC). Feed mixture, hay $(0.0306 \mathrm{mg} / \mathrm{kg} \mathrm{Se})$ and water were offered to lambs ad libitum. Foliar application of Se (Na-selenate, $10 \mathrm{~g} \mathrm{Se} / \mathrm{ha}$ ) occurred on corn hybrids Bergxxon (RWA, FAO group 400). Ingredients of feed mixtures and chemical composition of feed mixtures are presented in Table 1.

\section{Feed analyses}

Feed composition was determined with standard methods (AOAC 2006). The concentrations of minerals in solutions of digested feed samples were determined by inductively coupled plasma (ICP; Optima 2100 DV; PerkinElmer, Massachusetts, USA). All feed mixture samples were dried and ground into a fine powder using a heavy metal-free ultracentrifugal mill (ZM 200, Retsch GmbH, Haan, Germany) or knife mill (GM 200). All samples were digested with $10 \mathrm{ml}$ of a $5: 1$ mixture of $\mathrm{HNO}_{3}$ and $\mathrm{H}_{2} \mathrm{O}_{2}$ at $180{ }^{\circ} \mathrm{C}$ for 60 min in a microwave oven (Mars 6; CEM, North Carolina, USA). Each batch of samples run on the ICP was analysed with an internal pooled plasma control and with the reference material prepared in the same way as other plant samples. All samples were analysed in duplicate.

\section{Blood analyses}

Blood was collected from the jugular vein $(10 \mathrm{ml})$ on days 0 and 30 of experiment into serum vacutainer tubes and vacutainer tubes containing ethylenediamine tetra-acetic acid (EDTA) after morning feeding. Determination 
Table 1. Composition of feed mixture.

\begin{tabular}{lc}
\hline Ingredients & Feed mixture (\%) \\
\hline Corn & 23 \\
Barley & 38 \\
Wheat bran & 20 \\
Soybean meal & 4 \\
Extruded soybean & 14 \\
Mineral-vitamin premix* & 1 \\
Se content in corn (control group) & $0.014 \mathrm{mg} / \mathrm{kg}$ \\
Se content in BC (experimental group) & $0.278 \mathrm{mg} / \mathrm{kg}$ \\
Chemical composition (\%): & 90.21 \\
Dry matter & 15.62 \\
Crude proteins & 5.01 \\
Ether extract & 5.86 \\
Crude fibres & 6.15 \\
Ash & 7.7 \\
NEL, MJ ME/kg & 0.162 \\
Total Se content, mg/kg of feed mixture (control group) & 0.221 \\
Total Se content in BC, mg/kg of feed mixture (experimental group) & \\
\hline
\end{tabular}

BC - biofortified corn; NEL - net energy for lactation

*1 kg of mineral-vitamin premix contained: 1000000 I.U. vitamin A; 150000 I.U. vitamin $\mathrm{D}_{3}$; $1500 \mathrm{mg}$ vitamin E; $50 \mathrm{mg}$ vitamin $\mathrm{K}_{3} ; 100 \mathrm{mg}$ vitamin $\mathrm{B}_{1} ; 200 \mathrm{mg}$ vitamin $\mathrm{B}_{2} ; 200 \mathrm{mg}$ vitamin $\mathrm{B}_{6} ; 1 \mathrm{mg}$ vitamin $\mathrm{B}_{12} ; 500 \mathrm{mg} \mathrm{Ca}$ panthotenate; $1000 \mathrm{mg}$ niacin; $20000 \mathrm{mg}$ choline chloride; $4000 \mathrm{mg} \mathrm{FeSO}$; $800 \mathrm{mg} \mathrm{CuSO}$; $3500 \mathrm{mg} \mathrm{Mn}$ oxide; $5000 \mathrm{Zn}$ sulphate; $20 \mathrm{mg}$ cobalt chloride; $10000 \mathrm{mg} \mathrm{Mg}$ sulphate; $80 \mathrm{mg}$ potassium iodide.

of haematological indices including the number of leukocytes (WBC), erythrocytes (RBC) and thrombocytes (PLT), as well as the content of haemoglobin (HGB), haematocrit (HCT), mean corpuscular volume (MCV), the mean haemoglobin content in erythrocytes $(\mathrm{MCH})$ and the mean haemoglobin concentration in erythrocytes (MCHC) in whole blood of lambs was carried out on an automatic 3-part differential haematology analyzer Sysmex PocH-100Iv (Sysmex Europe GmbH, Hamburg, Germany).

Blood serum was separated by centrifugation $(10 \mathrm{~min})$ at 1,600 $\mathrm{g}$. Following indicators were determined in serum: mineral concentrations ( $\mathrm{Ca}$, inorganic $\mathrm{P}, \mathrm{Mg}, \mathrm{Fe})$, biochemical indices (urea, glucose, cholesterol, HDL-cholesterol, LDL-cholesterol, triglycerides, total protein, albumin, globulin, $\beta$-hydroxybutyrate [BHBA]) and enzyme activity (alanine aminotransferase [ALT], aspartate aminotransferase [AST], alkaline phosphatase [ALP], creatine kinase [CK] and $\gamma$-glutamyl transferase [GGT]). The concentration of BHBA was measured with the colorimetric method (RANBUT, Randox Laboratories Ltd., Crumlin, UK). All these indices were analyzed with Olympus AU400 (Olympus, Tokyo, Japan). Concentration of very low density lipoproteins (VLDL) was calculated with triglycerides $/ 5$.

The activity of glutathione peroxidase (GPx) in serum was determined by Ransel ${ }^{\circledR}$ kits (Randox Laboratories Ltd., Crumlin, UK) and the activity of total superoxide dismutase (SOD) with RANSOD ${ }^{\circledR}$ kits (Randox Laboratories Ltd., Crumlin, UK) on an automatic analyzer Olympus AU 400 (Olympus, Tokyo, Japan). In serum, concentrations of total triiodothyronine $\left(\mathrm{T}_{3}\right)$, thyroxine $\left(\mathrm{T}_{4}\right)$, and leptin concentrations were determined using commercial kit enzyme immunoassays (DE4568, DE4569, and DEE007, respectively), whereas the concentration of IGF-I was determined using commercial kit enzyme immunoassay for the quantitive determination of the human insulin-like growth factor (IGF-I) (DEE007) according to the ELISA procedure.

Carcass traits and tissue analyses

After slaughtering and exsanguination of 6 lambs per group, samples of the semimembranosus muscle (MS), liver, kidney, lungs, spleen, peritoneum and heart tissues were taken. Values of carcass colour were determined in MS 45 min after slaughtering. Values of pH1 were taken 45 min post mortem and pH2 $24 \mathrm{~h}$ after slaughter and cooling. The $\mathrm{pH}$ was measured with a handheld contact $\mathrm{pH}$ meter (Mettler Toledo, Greifensee, Switzerland) with a piercing type electrode. Values of colour were measured according to the CIE L* $\mathrm{a}^{*} \mathrm{~b}^{*}$ system (CIE 1976). Afterwords, the dressing percentage was calculated (live body weight - weight of carcass/100). The weighing and noting the body condition score of lambs was carried out according to Russel (1991) at every sampling. After that, daily gains of lambs were calculated. The concentrations of Se in solutions of digested samples of fresh animal tissues were determined with ICP. 
Statistical analyses

The mean values were obtained by the MEANS procedure of SAS $9.4^{\circledR}$. Analysis of variance was performed with the ANOVA procedure, and the differences between groups were processed with the Tukey test and declared at the level $P<0.05$ using the model:

$\mathrm{Y}_{\mathrm{ij}}=\mu+\mathrm{D}_{\mathrm{i}}+\mathrm{e}_{\mathrm{ij}}$

where: $\mathrm{Y}_{\mathrm{ij}}=$ dependent observation; $\mu=$ overall mean; $\mathrm{D}_{\mathrm{i}}=$ effect of diet treatment; $\mathrm{e}_{\mathrm{ij}}=$ residual.

\section{Results}

Feeding lambs with mixtures containing biofortified corn did not influence the production traits such as body weight, daily gain, or body condition score (Table 2) compared to the control. Similarly, the carcass traits of lambs, $\mathrm{pH}$ values and colour parameters of MS were not influenced by Se-BC (Table 3).

Table 2. Productive traits of lambs fed with feed mixtures containing biofortified corn.

\begin{tabular}{lrrrrr}
\hline Index & Day of measuring & \multicolumn{2}{c}{ Group } & SEM & $P$ \\
\cline { 3 - 5 } & & Control & Se-BC & & \\
\hline Body weight $(\mathrm{kg})$ & 0 & 22.83 & 23.23 & 0.40 & 0.64 \\
& 30 & 29.80 & 30.98 & 0.79 & 0.47 \\
Daily gain (g) & $0-30$ & 232.40 & 258.33 & 29.58 & 0.67 \\
Body condition score & 0 & 3.53 & 3.58 & 0.03 & 0.44 \\
& 30 & 3.58 & 3.76 & 0.06 & 0.17 \\
\hline
\end{tabular}

SEM - standard error means; Se-BC - feed mixture containing Se biofortified corn.

Table 3. Carcass traits, colour indices, and $\mathrm{pH}$ values of musculus semimebranosus of lambs fed with mixtures containing biofortified corn.

\begin{tabular}{lcccc}
\hline Carcass traits & \multicolumn{2}{c}{ Group } & SEM & $P$ \\
\cline { 2 - 3 } & Control & Se-BC & & \\
\hline Slaughter weight $(\mathrm{kg})$ & 30.05 & 29.58 & 1.12 & 0.85 \\
Hot carcass weight (kg) & 14.70 & 14.29 & 0.46 & 0.69 \\
Dressing (\%) & 48.90 & 48.53 & 0.65 & 0.80 \\
Forestomach and intestines (kg) & 8.15 & 8.16 & 0.46 & 0.99 \\
Organ weights* (kg) & 1.30 & 1.33 & 0.04 & 0.76 \\
Skin and lower legs (kg) & 3.85 & 3.44 & 0.17 & 0.27 \\
Colour indices and pH values & & & & \\
L & 36.88 & 36.97 & 0.15 & 0.79 \\
a & 15.48 & 15.27 & 0.14 & 0.48 \\
$\mathrm{~b}$ & 1.14 & 1.11 & 0.18 & 0.66 \\
$\mathrm{pH}_{1}$ & 6.79 & 6.81 & 0.03 & 0.79 \\
$\mathrm{pH}_{2}$ & 5.63 & 5.62 & 0.02 & 0.60 \\
\hline
\end{tabular}

SEM - standard error means; Se-BC - feed mixture containing Se biofortified corn;pH1 - 45 min post mortem, $\mathrm{pH} 2$ - $24 \mathrm{~h}$ post mortem; * weight of lungs, heart, liver and spleen.

Higher concentrations of Se in lungs and liver by $26.92 \%$ and $25.12 \%$, respectively, were determined in Se-BC lambs compared to control (Table 4). A tendency of increase $(P=0.05)$ in Se concentration was determined in spleen, with $18 \%$ of change, compared to control. While, concentrations of Se in MS, kidney, heart and peritoneum of lambs fed with 
Table 4. Concentrations of $\mathrm{Se}(\mathrm{mg} / \mathrm{kg}$ fresh matter) in different tissues of lambs fed with mixtures containing biofortified corn.

\begin{tabular}{|c|c|c|c|c|c|}
\hline \multirow[t]{2}{*}{ Tissue } & \multicolumn{2}{|c|}{ Group } & \multirow[t]{2}{*}{ Change (\%) } & \multirow[t]{2}{*}{ SEM } & \multirow[t]{2}{*}{$P$} \\
\hline & Control & Se-BC & & & \\
\hline MS & 0.13 & 0.13 & - & 0.02 & 0.99 \\
\hline Kidney & 1.07 & 1.19 & +11.21 & 0.06 & 0.15 \\
\hline Liver & 0.75 & 0.92 & +25.12 & 0.03 & 0.04 \\
\hline Heart & 0.23 & 0.24 & +4.35 & 0.01 & 0.59 \\
\hline Spleen & 0.33 & 0.39 & +18.18 & 0.01 & 0.05 \\
\hline Peritoneum & 0.03 & 0.04 & +33.33 & 0.01 & 0.55 \\
\hline Lungs & 0.26 & 0.33 & +26.92 & 0.01 & $<0.001$ \\
\hline
\end{tabular}

MS - musculus semimembranosus; SEM - standard error of mean; Se-BC - feed mixture containing Se biofortified corn

Se-BC did not differ compared to the control. By analyzing the haematological indices (Table 5), higher RBC, HGB, and HCT contents were determined in whole blood of Se-BC lambs. The activity of GPx in the serum of the experimental group at the end of the study was higher by $36.47 \%$ compared to the control (Fig. 1 ).

Table 5. Haematological indices of lambs fed with mixtures containing biofortified corn.

\begin{tabular}{|c|c|c|c|c|c|}
\hline \multirow[t]{2}{*}{ Indices } & \multirow[t]{2}{*}{ Time of measuring } & \multicolumn{2}{|c|}{ Group } & \multirow[t]{2}{*}{ SEM } & \multirow[t]{2}{*}{$P$} \\
\hline & & Control & Se-BC & & \\
\hline \multirow[t]{2}{*}{ WBC $\left(\times 10^{9} / 1\right)$} & 0 & 10.94 & 11.11 & 0.62 & 0.89 \\
\hline & 30 & 7.59 & 7.45 & 0.30 & 0.82 \\
\hline \multirow[t]{2}{*}{$\mathrm{RBC}\left(\times 10^{12} / 1\right)$} & 0 & 10.46 & 9.86 & 0.49 & 0.55 \\
\hline & 30 & 8.15 & 9.57 & 0.34 & 0.04 \\
\hline \multirow[t]{2}{*}{ HGB (g/l) } & 0 & 121.50 & 109.90 & 5.17 & 0.27 \\
\hline & 30 & 92.60 & 105.90 & 3.21 & 0.03 \\
\hline \multirow[t]{2}{*}{$\mathrm{HCT}(\mathrm{g} / \mathrm{l})$} & 0 & 0.39 & 0.38 & 0.02 & 0.84 \\
\hline & 30 & 0.34 & 0.38 & 0.01 & 0.03 \\
\hline \multirow[t]{2}{*}{$\operatorname{MCV}(f l)$} & 0 & 38.43 & 40.91 & 0.86 & 0.15 \\
\hline & 30 & 41.95 & 39.89 & 0.91 & 0.27 \\
\hline \multirow[t]{2}{*}{$\mathrm{MCH}(p g)$} & 0 & 11.75 & 11.27 & 0.30 & 0.44 \\
\hline & 30 & 11.46 & 11.11 & 0.19 & 0.36 \\
\hline \multirow[t]{2}{*}{ MCHC (g/l) } & 0 & 308.70 & 274.70 & 11.47 & 0.14 \\
\hline & 30 & 274.70 & 280.20 & 5.85 & 0.65 \\
\hline \multirow[t]{2}{*}{ PLT $\left(\times 10^{9} / 1\right)$} & 0 & 557.40 & 535.80 & 41.65 & 0.80 \\
\hline & 30 & 657.20 & 637.50 & 53.88 & 0.86 \\
\hline
\end{tabular}

SEM - standard error of mean; Se-BC - feed mixture containing Se biofortified corn; WBC - number of leukocytes; RBC - erythrocytes; HGB - contents of haemoglobin; HCT - haematocrit; MCV - mean corpuscular volume; $\mathrm{MCH}$ - average haemoglobin content in erythrocytes; MCHC - mean haemoglobin concentration in erythrocytes; PLT - platelet count

Activity of SOD was not affected when lambs were fed with Se-BC, compared to control (Fig. 2). Feeding lambs with Se-BC did not influence concentrations of Ca, P-inorganic, $\mathrm{Mg}, \mathrm{Fe}$ and $\mathrm{Se}$ in serum, while the rest of biochemical indices in serum did not differ in Se-BC lambs (Table 6). Concentrations of leptin, IGF-I, $\mathrm{T}_{3}$ and $\mathrm{T}_{4}$ in lambs' serum were not influenced by Se-BC (Table 7). 


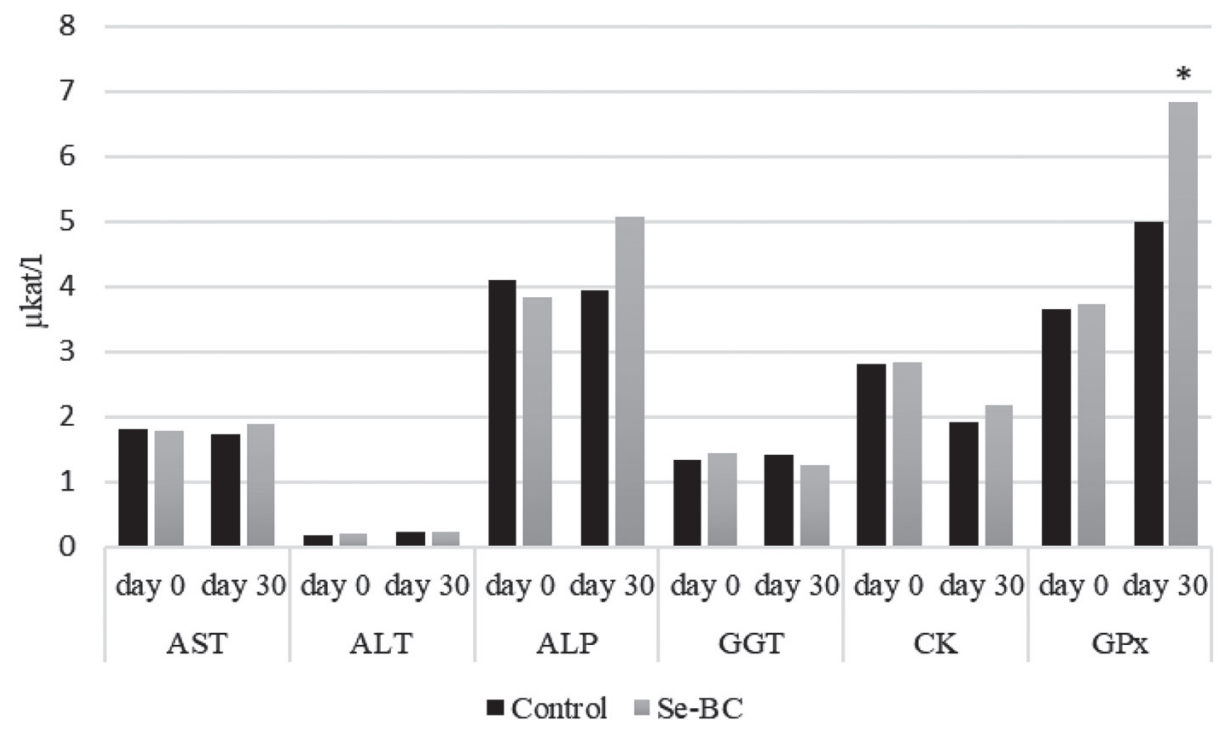

Fig. 1. Enzyme activities in serum of lambs fed with mixtures containing biofortified corn (Se-BC)

$* P<0.05 ;$ AST - aspartate aminotransferase; ALT - alanine aminotransferase; ALP - alkaline phosphatase; GGT $\gamma$-glutamyl transferase; CK - creatine kinase; GPx - glutathione peroxidase

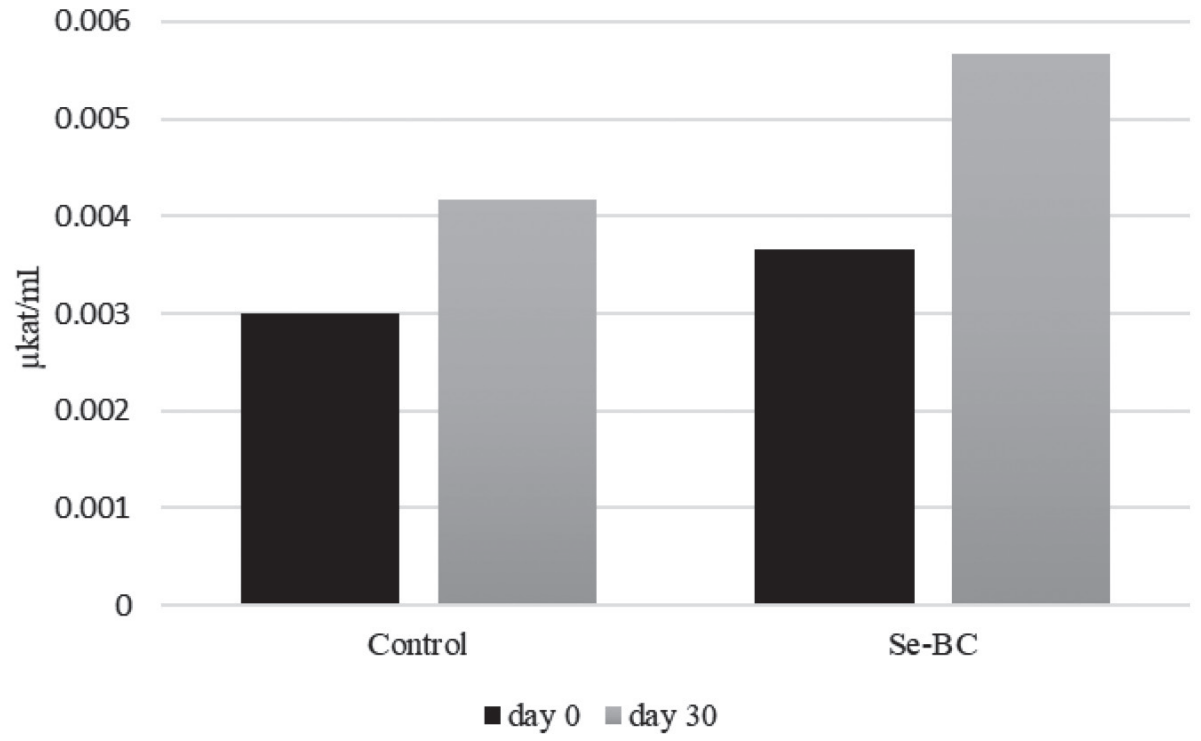

Fig. 2. Superoxide dismutase activity in serum of lambs fed with mixtures containing biofortified corn (Se-BC) 
Table 6. Biochemical indices in serum of lambs fed with mixtures containing biofortified corn.

\begin{tabular}{|c|c|c|c|c|c|}
\hline \multirow[t]{2}{*}{ Indices } & \multirow[t]{2}{*}{ Time of measuring } & \multicolumn{2}{|c|}{ Group } & \multirow[t]{2}{*}{ SEM } & \multirow[t]{2}{*}{$P$} \\
\hline & & Control & $\overline{\mathrm{Se}-\mathrm{BC}}$ & & \\
\hline \multirow[t]{2}{*}{$\mathrm{Ca}(\mathrm{mmol} / \mathrm{l})$} & 0 & 2.61 & 2.83 & 0.07 & 0.06 \\
\hline & 30 & 2.58 & 2.65 & 0.04 & 0.40 \\
\hline \multirow[t]{2}{*}{ P-anorganic (mmol/1) } & 0 & 2.78 & 3.10 & 0.12 & 0.17 \\
\hline & 30 & 2.72 & 2.87 & 0.05 & 0.47 \\
\hline \multirow[t]{2}{*}{$\mathrm{Mg}(\mathrm{mmol} / \mathrm{l})$} & 0 & 1.05 & 1.00 & 0.03 & 0.46 \\
\hline & 30 & 1.25 & 1.19 & 0.06 & 0.63 \\
\hline \multirow[t]{2}{*}{$\mathrm{Fe}(\mu \mathrm{mol} / 1)$} & 0 & 32.20 & 37.20 & 2.36 & 0.30 \\
\hline & 30 & 27.38 & 33.57 & 1.88 & 0.10 \\
\hline \multirow[t]{2}{*}{$\mathrm{Se}(\mathrm{mg} / \mathrm{l})$} & 0 & 0.06 & 0.05 & 0.004 & 0.49 \\
\hline & 30 & 0.12 & 0.13 & 0.003 & 0.52 \\
\hline \multirow[t]{2}{*}{ Glucose (mmol/l) } & 0 & 3.81 & 3.94 & 0.10 & 0.54 \\
\hline & 30 & 4.92 & 4.57 & 0.12 & 0.15 \\
\hline \multirow[t]{2}{*}{ Urea (mmol/l) } & 0 & 3.47 & 5.03 & 0.45 & 0.08 \\
\hline & 30 & 6.26 & 6.69 & 0.27 & 0.44 \\
\hline \multirow[t]{2}{*}{ Cholesterol (mmol/l) } & 0 & 2.38 & 2.35 & 0.19 & 0.94 \\
\hline & 30 & 1.37 & 1.40 & 0.08 & 0.90 \\
\hline \multirow[t]{2}{*}{ HDL- cholesterol (mmol/l) } & 0 & 1.19 & 1.15 & 0.07 & 0.76 \\
\hline & 30 & 0.69 & 0.79 & 0.04 & 0.22 \\
\hline \multirow[t]{2}{*}{ LDL-cholesterol (mmol/1) } & 0 & 1.04 & 1.09 & 0.12 & 0.85 \\
\hline & 30 & 0.57 & 0.50 & 0.05 & 0.53 \\
\hline \multirow[t]{2}{*}{ VLDL (mmol/1) } & 0 & 0.06 & 0.05 & 0.01 & 0.91 \\
\hline & 30 & 0.05 & 0.05 & 0.01 & 0.48 \\
\hline \multirow[t]{2}{*}{ Triglycerides (mmol/l) } & 0 & 0.32 & 0.24 & 0.03 & 0.14 \\
\hline & 30 & 0.25 & 0.23 & 0.02 & 0.49 \\
\hline \multirow[t]{2}{*}{ Total proteins $(\mathrm{g} / \mathrm{l})$} & 0 & 61.51 & 66.38 & 1.47 & 0.06 \\
\hline & 30 & 68.85 & 65.35 & 1.09 & 0.11 \\
\hline \multirow[t]{2}{*}{ Albumins (g/l) } & 0 & 30.30 & 32.68 & 0.69 & 0.06 \\
\hline & 30 & 30.24 & 31.27 & 0.42 & 0.23 \\
\hline \multirow[t]{2}{*}{ BHB (mmol/l) } & 0 & 0.31 & 0.33 & 0.03 & 0.79 \\
\hline & 30 & 0.32 & 0.36 & 0.02 & 0.33 \\
\hline
\end{tabular}

SEM - standard error of the mean; Se-BC - feed mixture containing Se biofortified corn; HDL - high-density lipoprotein; LDL - low-density lipoprotein; VLDL - very low-density lipoprotein; BHB - beta-hydroxybutyrate

Table 7. Concentrations of metabolic hormones in serum of lambs fed with mixtures containing biofortified corn.

\begin{tabular}{lrrrr}
\hline Tissue & \multicolumn{2}{c}{ Group } & SEM & $P$ \\
\cline { 2 - 5 } & Control & Se-BC & & \\
\hline Leptin $(\mathrm{ng} / \mathrm{ml})$ & 2.85 & 1.51 & 0.64 & 0.22 \\
IGF-I (ng/ml) & 341.33 & 265.65 & 54.43 & 0.52 \\
T3 (ng/ml) & 1.39 & 1.57 & 0.10 & 0.38 \\
T4 (nmol/l) & 80.47 & 81.20 & 5.95 & 0.96
\end{tabular}

SEM - standard error of mean; Se-BC - feed mixture containing Se biofortified corn; IGF-I - insulin-like growth factor; $\mathrm{T}_{3}$ - triiodothyronin; $\mathrm{T}_{4}$ - thyroxin 


\section{Discussion}

Feeding lambs with Se biofortified corn did not lead to any change in production traits, likely due to feeding with feed mixtures which were isoproteic, isolipidic and isoenergetic. Many studies determined an increased Se concentration in the liver and muscle with supplementation of Se in diets of lambs reared in a Se-deficient area (Qin et al. 2007; Antunović et al. 2009). Qin et al. (2007) indicated that Se concentrations were the highest in the kidneys, intermediate in the liver, and the lowest in the muscle of lambs. Similar range was determined in the present study, with the highest concentrations in the liver, and the lowest in MS of lambs, with increased deposition in liver and lungs in Se-BC lambs. Ranches et al. (2017) determined higher Se concentrations in the liver of calves fed biofortified hay $(7.7 \mathrm{mg} / \mathrm{kg} \mathrm{DM}$ of Se) compared to control $(0.1 \mathrm{mg} \mathrm{Se} / \mathrm{kg} \mathrm{DM})$, during 21 and 42 days. Also, in their study liver Se was much higher in lambs fed Se-enriched hay compared to lambs receiving sodium selenite in grain-based supplement.

Hall et al. (2013) concluded that in areas with low Se in forage, feeding beef calves with Se-enriched alfalfa hay during the weaning, improved growth and survival in the feedlot. Mehdi et al. (2015) determined increase of Se concentration in muscles, lungs, kidneys, liver and blood plasma of weaned calves fed diets containing $173 \mu \mathrm{g} / \mathrm{kg} \mathrm{DM}$ of Se in Se-enriched spelt and barley compared to control diet (58 $\mu \mathrm{g} \mathrm{Se} / \mathrm{kg} \mathrm{DM})$. Ranches et al. (2017) determined higher Se concentrations in plasma of weaned calves fed Se-biofortified hay, compared to control $(49.6 \mathrm{vs} .15 .7 \mathrm{ng} / \mathrm{ml})$. In the present study, the reason for the absence of significant increase of Se in muscle and serum of lambs was probably due to the fact that it was a short term study, and Se was determined in serum, not in whole blood. Weaned lambs in the first days consume less feed which can also be a limiting factor in Se storage in meat and blood. The above-mentioned suggests that lambs at the beginning of the study were Se-deficient because adequate levels of Se in blood of sheep are $0.12-0.15 \mathrm{mg} / \mathrm{l}$ as determined by Aitken (2001). One of the reasons could be that foliar application was usually found to be more efficient than soil application for Se (Gupta and Gupta 2017).

Significantly higher RBC, HGB and HCT content in whole blood of Se-BC lambs could be related to the protective effect of Se on cell membrane and organelles against oxidative damage and increase their life span (Shi et al. 2017). Positive influence of Se on haematological indices in Se-supplemented lambs was also determined by Faixova et al. (2007) in goat kids. The activity of the enzyme in the serum of the experimental group at the end of the study was significantly different only in GPx activity. Se-BC lambs had higher GPx activity in serum relative to control group by $36.47 \%$. Increase of GPx activity in serum of lambs fed with supplementation of organic Se in the Se deficient area was determined by numerous authors (Qin et al. 2007; Antunović et al. 2009; Antunović et al. 2013).

Concentrations of metabolic hormones in serum of lambs did not differ depending on the dietary treatments (Table 7). There was a noticeably higher but not significant concentration of $\mathrm{T}_{3}$ hormones in serum of Se-BC lambs compared to the control. Novoselec et al. (2017) found a significant increase in $T_{3}$ hormone activity during supplementation with Se in lactating sheep. Selenium supply is prioritised to the thyroid under conditions of Se restriction (Lyons 2018). Changes of blood thyroid hormone concentrations are an indirect measure changes in thyroid gland activity and circulating thyroid hormones, which can be considered as indicators of the metabolic and nutritional status of the animals. Concentration of leptin in the lambs' serum is influenced by the energy supply through diet (Antunović et al. 2010b). Serum leptin sensitivity to energy balance is reduced during periods of negative energy balance in sheep (Tokuda et al. 2001). The IGF-I plays a pivotal role in regulating the proliferation, differentiation and specific functions of many 
cell types (Baxter 1986). As determined in the present study, metabolic horomones such as $\mathrm{T}_{3}, \mathrm{~T}_{4}$, leptin and IGF-I were maintained when feeding lambs with Se-BC, which indicates preserved nutritional status due to energy balance.

The Se-BC in the lambs' diets maintained production traits, Se status and metabolic profile of lambs. Besides, it improved Se concentrations in lungs and liver, but not in the serum and MS indicating the posibility of using Se-BC in lambs' diets. Therefore, it is necessary to include biofortified corn containing different concentrations of Se in diets and longer duration of experiment in further research as well as use of biofortified corn, not only by foliar application but also in combination with soil. This will contribute to more comprehensive conclusions when using Se-BC in fattening lambs.

\section{Acknowledgement}

The study was carried out within the research team Innovative breeding and technological processes in animal production (No. 1126) at Faculty of Agrobiotechnical Sciences Osijek.

\section{References}

Ademi A, Gosmark E, Bernhoft A, Bytyqi H, Djikic M, Manojlović M, Lončarić Z, Drinić M, Filipović A, Singh BR 2015: Status selenium in sheep and dairy cow blood in Western Balkan countries. Acta Agriculturae Scandinavica, Section A Anim Sci 65: 9-16

Aitken P 2001: Se toxicity. Practice 23: 286-289

Antunović Z, Novoselec J, Klapec T, Čavar S, Mioč B, Šperanda M 2009: Influence of different selenium sources on performance, blood and meat selenium content of fattening lambs. Ital J Anim Sci 8: 163-165

Antunović Z, Novoselec J, Klir Ž 2017: Hematological parameters in ewes during lactation in organic farming. Poljoprivreda 23: 46-52

Antunović Z, Steiner Z, Vegara M, Šperanda M, Steiner Z, Novoselec J 2010a: Concentration of selenium in soil, pasture, blood and wool of sheep. Acta Vet-Beograd 60: 263-271

Antunović Z, Novoselec J, Sauerwein H, Vegara M, Šperanda M 2010b: Blood metabolic hormones and leptin in growing lambs. Poljoprivreda 16: 29-34

Antunović Z, Novoselec J, Šperanda M, Klapec T, Ćavar S, Mioč B, Klir Ž, Pavić V, Vuković R 2013: Influence of dietary supplementation with selenium on blood metabolic profile and thyroid hormones activities in fattening lambs. Pak Vet J 34: 224-228

AOAC 2006: Official methods of analysis of AOAC International. Association of Analytical Communities, Arlington, Virginia, USA.

Baxter RC 1986: The somatomedins: Insulin-like-growth factors. Adv Clin Chem 25: 49-115

Borg S, Brinch-Pedersen H, Tauris B, Holm PB 2009: Iron transport, deposition and bioavailability in the wheat and barley grain. Plant soil 325: 15-24

CIE-Commission Internationale de l'Eclairage, 1976: Colorimetry: Official Recommendations of the International Commission on Illumination. Publication CIE 15: E- 1.3.1. Bureau Central de la CIE, Paris, France.

Faixova Z, Faix Š, Leng L, Makova Z, Szaboova R 2007: Haematological, blood and rumen chemistry changes in lambs following supplementation with Se-yeast. Acta Vet Brno 76: 3-8

Giadinis ND, Loukopoulos P, Petridou EJ, Panousis N, Konstantoudaki K, Filiosssis G, Tsousis G, Brozos C, Koutsoumpas AT, Chaintoutis SC, Karatzias H 2016: Abortions in three beef cattle herds attributed to selenium deficiency. Pak Vet J 36: 145-148

Gupta M, Gupta S 2017: An overview of selenium uptake, metabolism, and toxicity in plants. Front Plant Sci 7: 2074

Hall J, Van Saun R, Nichols T, Pirelli G 2009: Comparison of selenium status in sheep after short-term exposure to high-selenium-fertilized forage or mineral supplement, Small Ruminant Res 82: 40-45

Hall JA, Bobe G, Vorachek W, Hugejiletu Gorman ME, Mosher WD, Pirelli GJ 2013: Effects of feeding seleniumenriched alfalfa hay on immunity and health of weaned beef calves. Biol Trace Elem Res 156: 96-110

Hall JA, Isaiah A, Estill CT, Pirelli GJ, Suchodolski JS 2017: Weaned beef calves fed selenium-biofortified alfalfa hay have an enriched nasal microbiota compared with healthy controls. PLoS ONE 12: e0179215

Li HF, McGrath SP, Zhao FJ 2008: Selenium uptake, translocation and speciation in wheat supplied with selenate or selenite. New Phytol 178: 92-102

Lyons G 2018: Biofortification of cereals with foliar selenium and iodine could reduce hypothyroidism. Front Plant Sci 9: 730

Malagoli M, Chiavon M, dall' Acqua S, Pilon-Smit EAH 2015: Effects of selenium biofortification on crop nutritional quality. Front Plant Sci 6: 280.

Mehdi Y, Clinquart A, Hornick JL, Cabaraux LI, Dufrasnem I 2015: Meat composition and quality of young growing Belgian Blue bulls offered a fattening diet with selenium enriched cereals. Can J Anim Sci 95: 456-473 
Novoselec J, Klir Ž, Domaćinović M, Lončarić Z, Antunović Z 2018: Biofortification of feedstuffs with microelements in animal nutrition. Poljoprivreda 24: 25-34

Novoselec J, Šperanda M, Klir Ž, Mioč B, Steiner Z, Antunović Z 2017: Blood biochemical indicators and concentration of thyroid hormones in heavily pregnant and lactating ewes depending on selenium supplementation. Acta Vet Brno 86: 353-363

Pešut O, Jovanović BI, Gvozdić D, Stojić V 2004: Selenium status of sheep and their lambs in the northern Serbian province of Vojvodina. Acta Vet-Beograd 54: 403-409

Qin S, Gao J, Huang K 2007: Effects of different selenium sources on tissue selenium concentrations, blood GSH-Px activities and plasma interleukin levels in finishing lambs. Biol Trace Elem Res 116: 91-102

Ranches J, Vendramini JMB, Arthington JD 2017. Effects of selenium biofortification of hayfields on measures of selenium status in cows consuming these forages. J Anim Sci 95: 120-128

Russel A 1991: Body condition scoring of sheep. In: Sheep and goat practice. Bailliere Tindall, Philadelphia; 3 p. SAS 9.4 ${ }^{\circledR}$, SAS Institute Inc., Cary, NC, USA

Séboussi R, Tremblay GF, Ouellet V, Chouinard PY, Chorfi Y, Bélanger G, Charbonneau É 2016: Seleniumfertilized forage as a way to supplement lactating dairy cows. J Dairy Sci 99: 5358-5369

Shi L, Ren Y, Zhang C, Yue W, Lei F 2017: Effects of maternal dietary selenium (Se-enriched yeast) on growth performance, antioxidant status and haemato-biochemical parameters of their male kids in Taihang Black Goats. Anim Feed Sci Tech 231: 67-75.

Stein A 2010: Global impacts of human mineral malnutrition. Plant Soil 335: 133-154

Tokuda T, Kimura D, Fujihara T 2001: The relationship between leptin and insulin in blood plasma of growing lambs. Anim Sci 73: 71-76

Valčić O, Jovanović I, Milanović S, Gvozdić D 2013: Selenium status of feedstuffs and grazing ewes in Serbia. Acta Vet-Beograd 63: 665-675

White PJ, Bowen HC, Parmaguru P, Fritz M, Spracklen WP, Spiby RE, Meacham MC, Mead A, Harriman M, Trueman LJ, Smith BM, Thomas B, Broadley MR 2004: Interactions between selenium and sulphur nutrition in Arabidopsis thaliana. J Exp Bot 55: 1927-1937 